\title{
LITERASI ULAMA DAN WACANA KEISLAMAN AWAL ABAD KE-20 DI SULAWESI SELATAN
}

\section{LITERACY ULAMA AND ISLAMIC DISCOURSE AT THE BEGINNING OF 20TH CENTURY IN SULAWESI SELATAN}

\author{
Abd. Kadir Ahmad \\ Balai Litbang Agama Makassar \\ Jl. AP. Pettarani No. 72 Makassar \\ Email: ahmadkadir56@gmail.com
}

Naskah diterima tanggal 28 Maret 2019, Naskah direvisi tanggal 26 April 2019, Naskah disetujui tanggal 30 Mei 2019

\begin{abstract}
Abstrak
Tulisan ini bertujuan (1) menggali karya tulis ulama khususnya awal abad ke-20 di Sulawesi Selatan, (2) mengidentifikasi wacana keagamaan yang berkembang saat itu, dan (3) mendorong pelestarian semangat literasi bagi ulama masa kini dan masa datang. Penulisan ini merupakan kajian pustaka dengan mengangkat karya tulis Haji Ahmad Bone dan Haji Makka, terbit tahun 1938 dan 1929. Analisis terhadap isi karya tulis tersebut dilakukan dengan menggunakan metode analisis isi (content analysis). Analisis terhadap kandungan karya tulis dikategorikan ke dalam tema besar ajaran Islam, yaitu akidah, syariah, dan akhlak. Dengan menggunakan kriteria tersebut akan diketahui kecenderungan wacana keislaman awal abad ke-20. Tulisan ini menemukan ulama di Sulsel memiliki latar belakang tradisi literasi yang kuat. Karya tulis dari Haji Ahmad Bone dan Haji Makka menunjukkan ujung dari sejarah panjang tersebut. Berdasarkan tiga tema Islam yang ditetapkan, tema syariah mendominasi wacana keislaman pada era tersebut. Tulisan berkontribusi mengungkap kekayaan karya tulis ulama hingga awal abad ke-20. Tugas ulama masa kini dan masa datang adalah melestarikan tradisi literasi tersebut.
\end{abstract}

Kata Kunci: literasi ulama, wacana keislaman, haji ahmad bone, haji makka

\begin{abstract}
This paper aims to (1) explore the writings of ulama especially in the early 20th century in South Sulawesi, (2) identify the religious discourse that developed at the time, and (3) encourage the preservation of the spirit of literacy for present and future scholars. This writing is a literature study on the writing of Haji Ahmad Bone and Hajj Makka, published in 1938 and 1929. Analysis of the contents of the paper was carried out using the content analysis method. Analysis of the content of the paper is categorized into the major themes of Islamic teachings, namely akidah, sharia, and akhlak. Using these criteria, we will find out the early 20th century Islamic discourse trends. This paper finds scholars in South Sulawesi with a strong background in literacy tradition. The writings of Haji Ahmad Bone and Haji Makka show the end of that long history. Based on the three Islamic themes established, the theme of sharia dominates Islamic discourse in that era. This writing contributes to uncover legacy of scholars' writings up to the beginning of the 20th century. The task of the present and future scholars is to preserve the literacy tradition.
\end{abstract}

Keywords: literacy of ulama, islamic discourse, haji ahmad bone, makka hajj 


\section{PENDAHULUAN}

$\mathrm{P}$ andangan tentang cakupan pengertian ulama dapat dilihat pada dua posisi. Pandangan yang melihat ulama sebagai ahli ilmu agama dalam arti sempit dan pandangan yang melihat ulama sebagai predikat untuk para ilmuan secara umum. Tulisan ini mengacu pada pandangan pertama seperti yang dipahami oleh Al-Jazairy (2001: 133) yang mengidentifikasi ulama sebagai orang-orang yang berilmu di bidang agama saja, bukan ulama dalam pengertian luas sebagaimana dimaksud oleh Shihab (1992: 382) berdasarkan pemahamannya terhadap sejumlah ayat alQur'an.

Secara doktrinal, Islam memosisikan ulama sebagai ahli waris para Nabi. Hal itu dikaitkan dengan fungsinya untuk melakukan (1) tablig atau menyampaikan ajaran Islam (QS.5 :67), (2) tibyan atau menjelaskan ajaran-ajaran Islam (QS.16:44), (3) tahkim menyelesaikan problem yang dihadapi masyarakat (QS.22:13), dan uswah atau menjadi contoh bagi masyarakat (Husein, 2002: 20).

Secara teoretis, Geertz menempatkan ulama sebagai penghubung antara Islam sebagai suatu ajaran dengan umatnya. Ia menyebutnya posisi ini sebagai cultural broker atau makelar budaya. Disebut demikian, karena ulama terutama yang disebutnya kiai di Jawa memahami dengan baik ajaran agama Islam dan budaya local (Geertz, 1960: 142). Posisi itu memungkinkan ulama mampu menjalankan tugasnya dengan baik. Horikoshi (1986: 115), menyebut empat garapan dasar yang menempatkan pengabdian ulama diperlukan dalam masyarakat. Ulama mengabdi di masjid, di pesantren, dan di sekolah dengan sistem kelas. Ulama bertindak sebagai imam salat lima waktu di masjid, dan sebagai khatib shalat Jumat. Selain itu, ulama juga mengadakan pengajian baik di masjid maupun di madrasah atau pesantren.

Status utama sebagai guru ini juga disebutkan oleh Pijper (1984: 72) ketika ia menggolongkan tiga kategori yang memerankan tugas keagamaan di dalam masyarakat, yaitu penghulu, guru agama swasta (ulama, kiai) dan pegawai agama rendahan di desa. Istilah guru agama swasta digunakan Pijper karena memang pada dasarnya fungsi utama ulama adalah sebagai guru. Ia juga melukiskan bahwa di kalangan orang-orang yang taat menjalankan agama, guru agama ini dianggap mempunyai kedudukan lebih tinggi dari pada penghulu. Guru agama atau kiai inilah yang menjadi elemen utama dalam sistem pesantren.

Secara kultural ulama di Sulsel disebut Gurutta (Bugis) atau Gurunta (Makassar). Ulama dalam konteks lokal ini harus memiliki kompetesi akademik (keilmuan berbasis kitab kuning), kompetensi kepribadian (maniniq), dan kompetensi sosial (memiliki hubungan baik dengan komunitas di mana ia hidup. Dalam pendidikan keagamaan ulama berperan sebagai pengasuh pondok pesantren, pembina pengajian, dan rujukan bagi masyarakat dalam soal-soal keagamaan dan sosial. Ulama juga berperan sebagai model (uswah), mediator dan motivator bagi perkembangan masyarakat (Ahmad, 2004: 364). Pelaksanaan fungsi di masyarakat ulama tidak hanya mengakomodir nilai-nilai budaya lokal yang tidak bertentangan dengan akidah dan syariah, tetapi juga melibatkan tokoh-tokoh tradisional lokal yang berpengaruh. Hanya dengan demikian, dakwah ulama dapat berjalan dengan mulus (Ahmad, 2019).

Ulama, dalam berdakwah bukan hanya memiliki kemampuan mentransfer pengetahuan keagamaan lewat lisan, tetapi juga dengan menggunakan tulisan atau literasi. Literasi ulama, dalam wujud karya tulis sejak awal masuknya Islam (1600-an) di kawasan ini sangat menonjol. Hal itu merupakan bagian dari perkembangan kesadaran literasi secara umum pada era tersebut. Tradisi literasi telah membuat perubahan, baik kasat mata maupun tersembunyi, dalam bidang politik dan budaya Makassar abad ke-16 dan ke-17 (Cummings, 2002: 108). Tradisi literasi juga dituangkan dalam bentuk syair yang bukan saja menjadi petunjuk ketinggian kesadaran intelektual ulama tetapi juga kehalusan jiwa dan kepekaan terhadap sejarah.

Entji' Amin, sekretaris Sultan Hasanuddin (1631-1670), yang mewakili Kerajaan Gowa dalam Perjanjian Bongaya, yang melibatkan Kerajaan Gowa dengan VOC (1667), mengabadikan peristiwa bersejarah tersebut dan 
perang Makassar dalam untaian syair yang sangat indah. Nuansa keislaman dalam syair sebanyak 534 bait itu amat kental, mengindikasikan penulisnya memiliki pemahaman mendalam tentang Islam. Dua bait syairnya berbunyi: Sudahlah kalah negeri Mengkasar/ Dengan kodrat Tuhan malik aldjabbarl Patik karangkan di dalam fatarl Kepada negeri yang lain supaya terkhabar. Selanjutnya ia menuliskan : Entji Amin itu empunya kalam/ Menceritakan perang kaum Islam/ Barang yang mati beroleh Islam/ Kemudiannya itu wallahu a'lam (Amin, 1963:218).

Kitab Akhbarul Akhirah (Kittaq Kanakana Alloribokowa) karangan Nur al-Din al-Raniri (1595-1658), yang diterjemahkan ke dalam Bahasa Makassar telah merupakan sumber tradisi pembacaan kitab ini menyusul peristiwa kematian dalam keluarga Makassar hingga sekarang (Gibson, 2001; Ahmad, 2009). Menurut Gibbon (2001:2), fenomena semacam ini merupakan fenomena global Islam in local setting. Ia menyebutkan satu naskah, Al-Durra Al-Fakhira karangan al-Ghazali (1058-1111) yang diterjemahkan ke dalam bahasa Makassar, sebagai bukti adanya proses globalisasi karya ulama dari pusat Islam ke tempat lain seperti di Ara, Bulukumba.

Syekh Yusuf (1626-1699) bukan hanya dikenang dengan makam yang "dikeramatkan" oleh masyarakat, karena ia seorang pejuang dan karenanya diangkat sebagai pahlawan nasional di dua negara: Indonesia dan Afrika Selatan. Ia pula bagian dari mata rantai tarekat (Tarekat Khalwatiyah Yusuf) dengan pengikut mulai dari Makassar, Afrika Selatan, hingga Asia Selatan, khususnya India. Ia lebih banyak dikenal karena ia mewariskan ajaran lewat tulisan. Setidaknya ia menulis 29 risalah yang ditulis dalam bahasa Arab baik ketika ia berada dalam pembuangan di Ceylon maupun ketika menghabiskan waktu pengasingannya di Cape Town. Risalah-risalah tersebut umumnya membahas di sekitar tasawuf dan tarekat (Hamid, 1994: 145). Hal ini merupakan bagian dari proses globalisasi Islam di mana Nusantara tidak hanya menyerap ilmu dari Barat tetapi sebaliknya menjadi bagian dari proses interaksi ilmiah yang saling memberi dan menerima. Dalam konteks seperti ini, bagian paling inti dari ajarannya ialah bahwa agama tersebut lebih besar dari komunitas-komunitas lokal dan tidak dapat dibatasi oleh batas-batas budaya suatu negara (Juergensmeyer (eds), 2003: 7).

Perkembangan literasi ulama di kawasan Timur Indonesia menunjukkan fenomena yang sama. Balai Litbang Agama Makassar menemukan dan telah membuat katalog naskah kuno bercorak Islam. Sebanyak 759 naskah berhasil dihimpun hingga tahun 2017, yang berasal dari basis-basis masyarakat Muslim di kawasan Timur Indonesia. Secara nasional Pusat Penelitian Lektur Keagamaan menginventarisir 1392 naskah sampai tahun 2008. Jumlah itu tentu sudah lebih banyak lagi jika diakumulasi dengan hasil temuan hingga tahun terakhir ini. Kriteria naskah (kuno) minimal usianya 50 tahun, namun temuan lapang menunjukkan kebanyakan naskah sudah berusia 100 tahun ke atas, terutama jika dilihat dari bahan kertas Eropa watermark yang digunakan (Idham, ed.,2017: xi). Jenis kertas seperti ini mulai berkembang di Italia dan kemudian seluruh Eropa sejak 700 tahun silam, dengan salah satu cirinya mengandung informasi tersembunyi (Kipper, 2003: 95). Jumlah itu pula tentu akan lebih banyak lagi jika dimasukkan naskah-naskah yang sudah dalam bentuk cetakan.

Perkembangan literasi ulama masih dapat ditelusuri jejaknya hingga awal abad ke20. Naskah-naskah keagamaan karya ulama masih digunakan oleh masyarakat hingga ke daerah-daerah terpencil sebagai sumber pembelajaran Islam. Hanya saja, sejak era tahun 1960-han bersamaan perkembangan lembaga pendidikan agama dalam bentuk pesantren dan madrasah, literasi ulama itu mulai surut (Ahmad, 2019: 215). Kitab-kitab klasik dan produksi buku-buku agama secara massif seakan merupakan palu godam tenggelamnya literasi ulama. Masalah yang dikaji dalam tulisan ini adalah profil ulama yang memiliki literasi keagamaan awal abad ke-20 di Sulawesi Selatan; (2) bentuk literasi yang dihasilkan, dan (3) orientasi wacana keagamaan yang berkembang pada era yang sama. Itulah sebabnya artikel ini ditulis dengan maksud (1) menggali karya tulis ulama khususnya awal abad ke-20 di Sulawesi 
Selatan, (2) mengidentifikasi wacana keagamaan yang berkembang saat itu, dan (3) mendorong pelestarian semangat literasi bagi ulama masa kini dan masa datang. Penulisan ini merupakan kajian pustaka dengan mengangkat karya tulis Haji Ahmad Bone dan Haji Makka, terbit tahun 1938 dan 1929. Analisis terhadap isi karya tulis tersebut dilakukan dengan menggunakan metode analisis isi (content analysis). Analisis terhadap kandungan karya tulis dikategorikan ke dalam tema besar ajaran Islam, yaitu akidah, syariah, dan akhlak. Dengan menggunakan kriteria tersebut akan diketahui kecenderungan wacana keislaman awal abad ke-20.

\section{PEMBAHASAN}

\section{Haji Ahmad Bone dan Haji Makka}

Dua sosok ulama menjadi kasus dalam tulisan ini, yaitu K.H. Ahmad Bone (1881-1972) dan Haji Makka (1887-1960). Keduanya hidup pada era bersamaan dan memiliki hubungan guru-murid. Kehadiran kedua ulama ini pada era peralihan abad ke-19 dan ke-20 memperpendek jarak masa kelam regenerasi ulama sejak era Syekh Yusuf (1626-1699) hingga tahun awal abad ke-20 di Sulawesi Selatan (selanjutnya ditulis Sulsel). Disebut masa kelam karena dalam kurun waktu tersebut tidak diketahui rentetan ulama yang menyambung regenerasi keulamaan hingga awal abad ke-20.

Ayah Ahmad Bone adalah seorang ulama besar yang dikenal sebagai Anregurutta Syekh Abdul Hayyi. Istilah Anreguru merupakan kualifikasi keulamaan tertinggi di Sulsel. Sementara gelar Syekh merupakan panggilan ulama yang digunakan pada umumnya dunia Islam. Abdul Hayyi adalah titisan ulama yang sekaligus menjabat sebagai qadli di Bone bernama Fakih Yusuf. Silsilah lengkapnya adalah Haji Ahmad bin Haji Abdul Hayyi bin Haji Yahya, bin Haji Musytari, bin Haji Harun, bin Faqih Yusuf, Qadli Bone.

Jika dikaitkan dengan nama kelahirannya, namanya adalah Ahmad bin Abdil Hayyi al-Bugisiy al-Bone al-Palakawiy (Pallakae) al-Cilallaniy (Cilellang) ibni Yahya. Ia dilahirkan di Kampung Cilellang Riaja, pada dini hari, malam Senin, tanggal 29 Rabiul Akhir $1298 \mathrm{H}$ atau 7 Maret $1881 \mathrm{M}$, bertepatan dengan tahun 2191 Rumiyah dan tahun 1597 Qibthiyah.
Ahmad Bone meninggal 18 Juli 1972 M/6-6$1392 \mathrm{H}$, dalam usia 91 tahun dalam hitungan tahun Masehi, dan 94 tahun menurut perhitungan tahun Hijriyah. Satu hal menarik dari hari kelahiran Ahmad Bone adalah dicantumkannya penanggalan Rumawi dan Qibthi bersamaan dengan tahun Hijriyah dan Masehi.

Pendidikannya diperoleh di Mekah dan Mesir, selama belasan tahun (mulai 1900), membuat kemampuannya dalam bidang agama sangat mumpuni. Dia juga merupakan bagian dari mata rantai pengajaran tarekat Syadziliyah dan Muhammadiyah di Sulawesi Selatan. Sebuah silsilah tarekat Syadziliyah yang dikeluarkannya ditemukan pada salah seorang muridnya di Jeneponto Kuat dugaan transmisi pengajaran tarekat tersebut dilakukan sejak berada di Timur Tengah. Salah seorang yang diberikan ijazah bernama Haji Sirajuddin alBugisiy. Penulisan kata al-Bugisiy biasanya dilakukan ketika yang bersangkutan berada di Timur Tengah untuk menunjukkan kebangsaan atau kesukuan (Ahmad, 2019: 73).

Sekembali dari belajar di Timur Tengah Ahmad Bone tidak kembali lagi ke tempat kelahirannya. Situasi Bone yang keamanannya kurang kondusif membuat keluarga besarnya pindah kawasan Bulukumba, namanya Batu Karopa, Bontomanai. Ayahnya, Anregurutta Abdul Hayyi menetap di sana hingga akhir hayat. Sementara itu, Ahmad Bone sendiri menghabiskan waktunya di Makassar. Rumahnya di kawasan Kampung Wajo, Makassar, disulap menjadi tempat pengajian bagi orang-orang yang haus ilmu agama. Awalnya dalam bentuk rumah kayu di sekitar Jalan Irian dan kemudian rumah kayu itu diangkut utuh ke Jalan Diponegoro. Tempat terakhir inilah yang menandai kiprahnya dalam bidang dakwah secara intensif.

Pada umumnya ulama yang mendalami agama Islam hingga paruh terakhir abad ke-19 mengaitkan nasab keilmuannya dengan Ahmad Bone. Hal ini terjadi pada ulama-ulama yang mendiami kawasan selatan Sulsel, mulai dari Makassar, Gowa, Jeneponto, hingga Bantaeng dan Bulukumba. Konsentrasi di wilayah selatan Sulsel dilakukan sebagai bagian dari strategi dakwah di mana wilayah utara menjadi tugas ulama-ulama yang berpusat di Sengkang di 
bawah pengaruh ulama besar Muhammad As'ad. Selain menjadikan Makassar sebagai pusat dakwah, Ahmad Bone juga membuat sentra pengajian yang berpusat di Arungkeke Jeneponto (80 km dari Makassar) (Ahmad, 2019: 36). Tempat ini mudah diakses murid-murid dari Gowa, Jeneponto, Bantaeng dan Bulukumba. Keberadaan pusat pengajian di daerah ini ditunjang oleh fasilitasi raja-raja lokal yang memerintah kerajaan kecil tersebut.

Hubungan Ahmad Bone dengan daerah Makassar ditunjang oleh latar belakang keluarga. Istrinya sendiri Hawang Daeng Sagala berasal dari Sungguminasa, Gowa, dan menantu dari anak perempuan pertamanya adalah pedagang kaya yang berlatarbelakang keluarga Jeneponto bernama Haji Mannya Daeng Lawa. Tiga orang anak Ahmad Bone adalah perempuan. Latar belakang sosial dan ekonomi seperti itu membuat kiprahnya di bidang dakwah memiliki basis yang kuat.

Jika organisasi ulama dalam bentuk Majelis Ulama Indonesia (MUI) baru berdiri tahun 1975, maka sebelum Indonesia merdeka di Sulawesi Selatan sudah berdiri suatu organisasi ulama yang dipimpin oleh Ahmad Bone. Organisasi ini merupakan sebuah majelis ulama yang diberi nama Musyawarah Ulama Syafiiyah berdiri 21-9-1938 bertepatan 26 Rajab $1357 \mathrm{H}$. Pada awal berdirinya organisasi ini dipimpin oleh Haji Ahmad Bone, sebagai Ketua, Haji Muhammad Ramli sebagai katib. Tuan Muhammad Nuruddin Daeng Paliweng sebagai wakil Ketua, Tuang Haji Abdullah sebagai bendahara. Kepengurusan dilengkapi dengan beberapa pembantu dan komisi (Bone, 1938: 284).

Salah satu tujuan organisasi ini adalah memberikan penjelasan dan fatwa kepada umat Islam terkait masalah-masalah keagamaan yang muncul. Lembaga ini memiliki kewenangan dalam hal fatwa saja. Dijelaskan, keberadaan fatwa dalam Islam disebut sebagai fardu kifayah (parallu kipayah). Fatwa dibagi ke dalam dua bagian. Pertama, fatwa dalam bentuk istinbath artinya mengeluarkan hukum (bicara sara') dari Al-Qur'an atau Hadis melalui ijtihad. Kedua, fatwa naqli artinya "menyalin" (appalemba) dari kitab-kitab muktamad atau riwayat yang bersumber dari mufti ahli. Berdasarkan kriteria tersebut, posisi panrita muqallid (ulama yang mengikuti mazhab) berada pada jenis fatwa kedua; sementara fatwa pertama merupakan bagian dari fungsi ulama mujtahid (pammentenganna tupanrita mujtahidka). Dalam hal ini, majelis fatwa menempatkan diri mereka dalam otoritas fatwa jenis kedua (Bone, 1939:381). Untuk melaksanakan fatwa, organisasi ini mengagendakan mulaqah (pertemuan) setahun sekali.

Musyawarah Ulama Syafiiyah menjadi cikal bakal berdirinya Rabithatul Ulama pada 8 April 1950, yang juga merupakan perhimpunan ulama-ulama Ahlussunnah Waljamaah. Haji Ahmad Bone kembali menjadi Ketua, Haji Muhammad Ramli sebagai wakil ketua, dan Haji Saifuddin sekretaris, sementara H. Sayyid Jamaluddin Puang Ramma sebagai ketua bidang dakwah. Rabithah Ulama bertujuan memberikan pertimbangan kepada pemerintah mengenai masalah keagamaan dan menjadi berhimpun ulama melakukan pengkajian agama atau bahtsul masail, termasuk wadah pengaderan ulama. Perhimpunan ulama ini kemudian mempermudah jalan pembentukan pengurus wilayah NU Sulsel tahun 1953, yang juga diarsiteki oleh ulama -ulama (Ramly, Ahmad, Masroer, 2006: 104). Pada tahun-tahun akhir masa hidupnya, Ahmad Bone sempat mengabdi di jabatan formal pemerintahan. Saat itu, Menteri Agama membentuk Mahkamah Syari'ah Makassar, yang wilayah kerjanya meliputi Sulawesi, Bali, Nusa Tenggara Barat, Nusa Tenggara Timur, Maluku dan Irian Jaya. K.H. Ahmad Bone dipercayakan sebagai ketua lembaga baru tersebut (1958-1962).

Kalau Haji Ahmad Bone lahir dari nasab ulama, maka Haji Makka di Sungguminasa lahir dari kalangan birokrat zaman Belanda. Ayahnya bernama Haji Abdul Rajab, asli orang Gowa, dan tinggal di Jongaya. Belanda kemudian mengirimnya ke Panglime, Lamurukung, Bone, sebagai seorang pegawai Syahbandar. Di sana ia kawin dengan seorang gadis setempat, bernama Sitti Ara Daeng Satting, yang masih keturunan Qadi Bone. Di sana pulalah Haji Makka lahir. Keturunan campuran Bugis-Makassar, ia kemudian dipanggil Haji Makka dan Puang Makka. Ia sendiri memilih menggunakan nama Haji Makka dalam tulisan-tulisannya. Nama 
lengkapnya Haji Makka Daeng Mattayang. Haji Makka pertama kawin dengan Daruma Daeng Ngai binti Sarasang Daeng Mile bin Pannyu. Berselang kemudian, ia kawin lagi dengan Maemuna Daeng Pati (Haji Lolo) binti Taha.

Sama dengan Ahmad Bone, awal-awal kehidupan masa mudanya dihabiskan mengaji di Mekah. Sebelum ke Mekah, ia terlebih dahulu belajar ke K.H. Ahmad Bone. Sekembali dari Mekah ia tidak lagi tinggal di tempat kelahirannya, Panglime. Ia memilih pulang ke kampung keluarga ayahnya di Gowa. Amanah dari kerajaan sudah menantinya, menjadi pelayan peziarah di makam Syekh Yusuf di Lakiung, Katangka. Hanya berselang beberapa lama ia diminta lagi pindah ke ibu kota kerajaan Gowa, di Sungguminasa. Di sana ia diangkat sebagai Imam, jabatan di bawah Kadi, yang bergelar Daenta Kaliya di Gowa. Jabatan imam itulah yang diemban hingga akhir hayatnya. Bahkan merupakan jabatan turun temurun hingga cucunya sekarang ini. Sama dengan Haji Ahmad Bone, ia juga diberi tugas lain memimpin NU yang di bentuk di Gowa tahun 1950. Ia mendapat kehormatan duduk di "Dewan Perwakilan Rakyat" mewakili NU (Ahmad, 2019: 17).

Dua tantangan bagi Haji Makka setelah berada di Sungguminasa, yaitu terbatasnya masjid dan tidak adanya lembaga pendidikan. Pusat Kerajaan Gowa saat itu hanya memiliki dua masjid, yaitu masjid tua Katangka dan satu lagi di Taeng di pinggiran kota. Ia bersama masyarakat dan didukung oleh kerajaan membangun masjid (1924) yang kemudian bernama Masjid Jami AL-Istiqamah sekarang ini. Ia juga membangun Madrasah Alhusainiyah, di samping masjid tersebut. Madrasah inilah satu-satunya lembaga pendidikan agama saat itu tempat belajar masyarakat daerah sekitarnya (Ahmad, 2019: 21).

\section{Literasi Ulama}

Ahmad Bone dan Haji Makka memiliki keistimewaan di kalangan ulama yang hidup pada masa peralihan abad ke-19 ke abad ke-20. Keduanya memiliki legacy (warisan) dalam bentuk karya tulis. Ahmad Bone sendiri menerbitkan majalah Azzikra dan Haji Makka menerbitkan risalah Al-Ahukumu Al-Syar'iyah. Perbedaannya hanya dalam bentuk volume, frekuensi dan wilayah distribusi. Penyebarannya meliputi daerah Celebes (Sulawesi), Kalimantan, hingga Sumatera. Majalah ini merupakan majalah bulanan, mulai terbit pada bulan Ramadlan tahun $1356 \mathrm{H}$, bertepatan bulan November 1938. Bahagian depan dengan hard cover tertulis nama "Majallah Al-Zikra" dalam tulisan Arab kaligrafis. Majalah ini ditulis dalam Bahasa Bugis dan Makassar, sementara AlAhukumu Al-Syar'iyah dalam Bahasa Makassar saja.

Pengertian singkat alquran, Hadits, Ijmak, dan Qiyas dicantumkan mengelilingi kulit (halaman depan), sementara di tengahnya tercantum paham yang diikuti yaitu Muhammad bin Idris Al-Syafii dan Mazhab Ali bin Ismail Al- Asy'ary. Seperti jurnal masa kini, penomoran halaman dilakukan secara bersambung dari terbitan pertama hingga terakhir. Jumlah keseluruhannya 386 halaman selama 12 kali terbit.

Sebagaimana namanya majalah ini berfungsi sebagai peringatan tentang agama dan hikmah. Kandungannya didominasi penjelasan tentang syariah terutama ibadah mahdah dan akidah. Selebihnya pembinaan akhlak berupa nasihat dan kata-kata hikmah. Penerbitnya adalah Ahmad Bone dan merupakan penulis utama. Beberapa ulama berfungsi sebagai kontributor, seperti Haji Muhammad Ramli, Haji Muhammad Asad (Sengkang), Haji Abdullah (Kadi Donggala), Haji Nuruddin Daeng Paliweng (Maros), Haji Muhammad Thahir (Kadi Balangnipa), Haji Abdul Gani (Pasir). Kontributor juga termasuk Haji Muhammad Daud Ismail (Cenrana), Muhammad Abduh (Allekkuang) dan Muhammad Yunus (Belawa). Ketiganya menamakan dirinya anak sekolah (murid) dari Sekolah Arab Sengkang.

Berbeda dengan Azzikra, Al-Hukumu AlSyar'iyah tulisan Haji Makka, lebih mirip risalah bulanan. Terbit dalam bentuk cetakan secara periodik, setiap tanggal 10 bulan berjalan. Hanya dua terbitan yang masih ditemukan pada kepemilikan keturunannya. Terbitan nomor 2, terbit tanggal 10 April 1929 dan terbitan nomor 3 terbit pada tanggal yang sama bulan Mei 1929. 
Majalah ini terbit lebih awal dari Majalah Azzikra binaan Haji Ahmad Bone.

Meski merupakan terbitan bulanan, tulisan ini disebut dengan nama kitab oleh pengarangnya. Disebutkan pada kulit kitab: iaminne kittaq nakaranga Haji Makka Imang Sungguminasa niarenga al-Hukumusy Syar'iyah. Artinya, kitab ini dikarang oleh Haji Makka, Imam Sungguminasa diberi nama alHukumusy-Syar'iyah. Pada bagian bawah tertulis nanipassuluq anne kittaka sikali ilalangna tassibulanga. Artinya, kitab ini diterbitkan sekali dalam sebulan (Ahmad, 2019: 29).

Pada bagian kulit depan di bawah identitas buku dan pengarang terdapat semacam quote dari ayat Al-Quran. Di bawah tulisan AlQuran tersebut dituliskan potongan ayat tanpa menyebutkan surah dan ayat nomor ayat. Haji Makka merupakan penulis tunggal dan tidak ada interaksi dalam bentuk pertanyaan dari masyarakat. Kelihatannya, kitab ini diperuntukkan sebagai media pengajaran lebih dari sebuah media pencerahan masalah-masalah yang muncul di masyarakat secara interaktif.

\section{Wacana Keagamaan}

Wacana keagamaan dapat dipahami dari materi yang dituliskan dan dari sejumlah pertanyaan yang muncul dari masyarakat yang termuat dalam Azzikra. Hal itu pula dapat dipandang sebagai fenomena keberagamaan yang mewakili semangat zamannya. Jika dilihat dari kategorisasi aspek-aspek ajaran Islam, yaitu akidah, syariah dan akhlak, maka semua aspek terwakili di dalam wacana tersebut. Pendekatan majalah terhadap aspek-aspek ajaran Islam bersifat tematis. Pemilihan ayat dan hadis serta pandangan para ulama digunakan untuk mendukung tema yang diangkat. Tema-tema besar mulai dari syariat dan keimanan atau akidah mendominasi wacana keagamaan, menyusul kemudian tema tentang akhlak dan tasawuf.

Tema tentang syariat atau fiqh menyebar ke hampir semua nomor (terbitan). Diawali dengan tema puasa (nomor 1), zakat (nomor 2), kurban (nomor 3), kewajian beribadah (nomor 5), haji (nomor 8 dan 9), kewajiban salat Jumat (nomor 12), akikah (nomor 3), dan amalan-amalan yang disunantkan dalam bulan Haji, Muharram (nomor 4). Tema akidah atau keimanan berkisar pada wacana tentang sifat-sifat Allah dan kenabian (nomor 4), malaikat (nomor 5), Nabi Muhammad dan keluarganya (nomor 6) hari kemudian dan pemeriksaan dalam kubur (ke-7 dan 9), bangkit dan berkumpul di Padang Mahsyar (nomor 10), serta hari kiamat (nomor11). Tema tentang akhlak misalnya tentang persatuan, disiplin waktu, persaudaraan sesama muslim (nomor 8). Khusus tentang tema tasawuf membahasa Nur Muhammad (nomor 5 dan 6).

Adapun wacana keagamaan yang termuat dalam Al-Hukumu Al-Syar'iyah, karya Haji Makka, lebih menekankan pada tiga sub tema, yaitu tafsir, fiqh tentang salat, dan barzanji. Ketiga sub tema ini relevan dengan posisinya penulisnya sebagai Imam, yang banyak memberikan pelayanan praktis kepada masyarakat. Namun demikian, pemilihan ayatayat yang ditafsirkan dikaitkan dengan tema akidah, syariah, dan akhlak.

Respons masyarakat cukup tinggi terhadap eksistensi majalah Azzikra. Pembacanya tidak hanya berasal dari Sulawesi Selatan tetapi juga dari. Sulawesi Tenggara, Sulawesi Tengah, Kalimantan Timur dan Sumatera. Hal ini terlihat dari mereka yang mengirimkan pertanyaan kepada redaksi. Ada 36 orang yang merespons dan memberikan pertanyaan kepada Azzikra. Penanya tertentu mengajukan lebih dari satu kasus. Asal daerah penanya dapat dilihat pada tabel di bawah ini.

Tabel 1. Jumlah Penanya Menurut Provinsi

\begin{tabular}{|llll|}
\hline No. & Provinsi & F & $\%$ \\
\hline 1 & Sulawesi Tengah & 4 & 11 \\
2 & Riau & 2 & 5,5 \\
3 & Sulawesi Selatan & 27 & 75 \\
4 & Sulawesi Tenggara & 2 & 5,5 \\
5 & Kalimantan Timur & 1 & 3 \\
& Jumlah & 36 & 100 \\
\hline
\end{tabular}

Seperti terlihat pada tabel penanya didominasi dari Sulawesi Selatan, menyusul Sulawesi Tengah kemudian Sulawesi Tenggara dan Riau. Mereka yang merespons merupakan bagian dari pusat dan kantong-kantong diaspora Bugis-Makassar di perantauan, seperti Donggala di Sulawesi Tengah, Kendari di Sulawesi 
Tenggara, Indragiri di Riau, dan Kutai di Kalimantan Timur. Khusus Sulawesi Selatan kebanyakan respons datang dari Mamuju (22 persen), Palopo (11 persen), Maros (8 persen) dan Majene, Bulukumba, Malili, dan Masalembo (masing-masing 5 persen).

Wacana keagamaan yang terangkat ke permukaan merupakan sesuatu yang merupakan pengalaman pribadi atau praktik keagamaan yang ada di lingkungan mereka. Misalnya, pertanyaan dari Pulau Masalembo mempertanyakan cara memandikan dan menyembahyangkan potongan mayat yang meninggal karena tenggelam di laut. Begitu kasus gadai pohon kelapa yang diangkat oleh penanya dari Majene. Demikian juga pertanyaan dari

Bulukumba tentang status salat Jumat di dua masjid yang berdekatan. Pertanyaan dari Donggala di daerah yang kekurangan air mengalami junub di malam bulan Ramadan sementara mereka ingin salat jamaah Subuh di masjid.

Lain lagi pertanyaan dari Mamuju yang meminta penjelasan bahwa yang menyembah (hamba) dan yang disembah (Allah) satu saja. Fenomena sosial keagamaan seperti itu hanya contoh dari sekian banyak terjadi di masyarakat. Demikian juga pertanyaan dari Makassar tentang status salat Jumat pada hari lebaran. Persoalan lain dari Sidenreng mengangkat kasus khotbah dengan menggunakan bahasa daerah, bukan bahasa Arab. Secara keseluruhan terdapat 50 pertanyaan yang diangkat oleh penanya yang jika dikategorikan secara tematik, dapat dilihat pada tabel berikut.

Tabel 1. Banyaknya Pertanyaan Menurut Tema

\begin{tabular}{|llll|}
\hline No. & Tema & F & $\%$ \\
\hline 1 & Akidah & 9 & 18 \\
2 & Syariah & 37 & 74 \\
3 & Akhlak/tasawuf & 4 & 8 \\
& Jumlah & 50 & 100 \\
\hline
\end{tabular}

Wacana keagamaan yang paling banyak mendapat respons masyarakat adalah masalah Fiqhi atau syariah, menyusul masalah keimanan atau akidah, dan akhlak/tasawuf . Masalah Fiqhi yang paling diperbincangkan adalah sub tema munakahat termasuk kewarisan (22 persen), menyusul taharah dan salat (masing-masing 18 persen), dan jual beli (12 persen). Hal ini menunjukkan gambaran masyarakat yang sangat berorientasi Fiqh atau normatif dalam beragama. Hal-hal yang bersifat fundamental dalam bidang akidah dan akhlak mendapatkan porsi yang tidak seimbang, sehingga totalitas agama yang merupakan kesatuan dari akidah, syariah, dan akhlak menjadi timpang.

\section{PENUTUP}

Sejarah ulama di Sulsel pada dasarnya memiliki latar belakang tradisi literasi yang kuat. Hal itu terbukti dengan banyaknya naskah keagamaan yang ditemukan sejak abad permulaan Islam di kawasan ini hingga paruh pertama ke-20. Naskah-naskah ulama dalam berbagai bidang dan tema serta orientasi keberagamaan tersebar hingga ke pelosokpelosok negeri. Masyarakat menjadikannya sumber pembelajaran baik secara terstruktur maupun mandiri. Bahkan ketiadaan ulama di sebuah era atau komunitas Islam tetap mengalami proses internalisasi ajaran agama lewat peninggalan naskah ulama sebelumnya yang diajarkan dan dilestarikan oleh guru-guru kampung.

Literasi ulama masih dapat ditemukan awal abad ke-20 setidaknya dari dua ulama yang menjadi kasus dalam tulisan ini, yaitu Haji Ahmad Bone dan Haji Makka. Literasi itu memiliki dua keuntungan: dapat membawa pembaca mengenali produktivitas ulama dalam bidang tulis menulis dan menginformasikan orientasi keberagamaan yang dominan pada zaman sebelum kemerdekaan tersebut. Kecenderungan penurunan literasi ulama khusus dalam produksi karya tulis sejak selepas pertengahan abad ke-20, seiring dengan perkembangan pesat lembaga pendidikan Islam menjadi tantangan tersendiri bagi ulama sekarang ini dan ke depan. Tugas ulama adalah mengisi kekosongan tersebut yang ternyata diisi oleh produktivitas dan semangat literasi yang tinggi di luar kalangan ulama yang otoritatif. 


\section{UCAPAN TERIMA KASIH}

Penulis mengucapkan penghargaan dan terima kasih yang setinggi-tingginya kepada para kerabat ulama yang menjadi subyek penelitian saya selama ini. Terutama keluarga K.H. Ahmad Bone, Haji Makka, K.H Ahmad Daeng Mappuji, K.H.Hayyong. Terima kasih pula saya sampaikan kepada semua pihak yang turut berjasa sehingga penelitian tentang peran ulama dalam masyarakat dapat berjalan dengan baik. Terima khusus saya sampaikan kepada pimpinan dan peneliti, dan staf Balai Penelitian dan Pengembangan Agama Makassar atas dukungan kelembagaan sehingga tulisan ini dapat terwujud. Semoga tulisan ini berguna bagi pengembangan pengetahuan dan pengabdian kepada kemanusiaan.

\section{DAFTAR PUSTAKA}

Ahmad, Abd. Kadir. 2019. Ulama, Guru, dan Gallarrang: Negosiasi Islam dan Lokalitas. Bantul: Lintas Nalar.

Ahmad (ed) Abd. Kadir. 2009. Akhbarul Akhirah: Kittaq Kana-kana Alloribokowa. Makassar: Balai Penelitian dan Pengembangan Agama Makassar.

Ahmad, Abd. Kadir. 2004. Ulama Bugis. Makassar: Indobis.

Aljazairy, Abu Bakar Jabir. 2001. Ilmu dan Ulama (Tej) Asep Saefullah dan Kamaluddin Sa'diyatulharamain. Jakarta : Pustaka Azzam.

Bone, Ahmad. 1928. 'Musyawarah Ulama Syafiiyah', Majalah Azzikra, 9/1.

Cummings, William. 2002. Making Blood White: Historical Transformations in Early Modern Makassar. Honolulu: University of Hawai'i Press.

Entji' Amin. 1963. Sjair Perang Mengkasar (Tej) C. Skinner. Leiden: S-GravenhageMartinus Nijhoff.
Geertz, Clifford. 1960. 'The Javanese Kijaji: The Changing Role of a Cultural Broker', Comparative Studies in Society and History $2 / 2$.

Gibson, Thomas.2001. 'The Legacy of Shaikh Yusuf in South Sulawesi', paper presented at the workshop on Traditions of Learning and Networks of Knowledge, in the series on the Indian Ocean: Trans-regional Creation of Societies and Cultures, sponsored by the Institute of Social and Cultural Anthropology. Oxford University, 29-30 September.

Hamid, Abu. 1994. Syekh Yusuf Makassar: Seorang Ulama, Sufi, dan Pejuang. Jakarta: Yayasan Obor Indonesia.

Horikoshi, Hiroko. 1987. Kyai dan Perubahan Sosial. Jakarta: P3M.

Husein, Mochtar. 2002. Tugas Ulama dalam alQur'an. Jakarta: Yayasan Dar AlHukama.

Idham (ed). 2017. Katalog Naskah Keagamaan, Maluku Utara, Sulawesi Selatan, Kalimantan Timur, Sulawesi Barat, Maluku, Gorontalo, Sulawesi Tenggara, Papua Barat. Makassar: Balai Litbang Agama Makassar.

Juergensmeyer, Mark (eds). Global Religions: An Introduction. England:Oxford University Press, 2003.

Kipper, Gregory. 2003. Investigator's Guide to Steganography. Boca Raton, London, Bew York, Washington,D.C.: Auerbach Publications.

Pijper, G.F. 1984. Beberapa Studi tentang Sejarah Islam di Indonesia 1900 - 1950 (Tej) Tudjimah dan Yessi Augusdin. Jakarta: UI Press.

Ramly, Andi Muawiyah; Ahmad, Abd. Kadir; dan Masroer,Ch,Jh. Mukhlas.2006. Demi Ayat Tuhan, Upaya KPPSI Menegakkan Syariat Islam. Jakarta: Opsi.

Shihab, Quraish. 1992. Membumikan AlQur'an. Jakarta: Mizan. 
210 | Jurnal “Al-Qalam” Volume 25 Nomor 1 Juni 2019 